\title{
Faktor-Faktor Produksi yang Mempengaruhi Usaha Pembibitan Sapi Bali di Kelompok Tani Cipta Kasih Desa Kuaken Kecamatan Noemuti Timur
}

Adryanto Charles Nahak ${ }^{\mathrm{a}}$

${ }^{a}$ Fakultas Pertanian, Universitas Timor, Kefamenanu, TTU - NTT, Indonesia

\section{Article Info}

\section{Article history:}

Received 11 Juni 2018

Received in revised form 5 Juli 2018

Accepted 13 Juli 2018

DOI:

https://doi.org/10.32938/ja.v3i3.412

Keywords:

Analisis Faktor Produksi, Pembibitan, Sapi Bali

\section{Abstrak}

Sapi Bali merupakan salah satu komoditi unggulan dan penggerak roda perekonomian di Kabupaten Timor Tengah Utara. Selama in kendala utama petani dalam meningkatkan populasi ternak sapi bali adalah keterbatasan jumlah sapi bibit. Salah satu penyebabnya adalah banyak sapi betina produktif yang dipotong, dan pengelolaan sistem usaha ternak yang masih belum dikelola dengan baik. Penelitian ini bertujuan untuk mengetahui faktor- faktor produksi apa saja yang berpengaruh terhadap usaha pembibitan sapi bali di Kelompok Tani Cipta Kasih, Desa Kuaken, Kecamatan Noemuti Timur, Kabupaten Timor Tengah Utara. Penelitian ini dilaksanakan selama 1 (satu) bulan yakni pada bulan Mei 2018 sampai dengan selesai. Metode yang digunakan dalam penelitian adalah metode survey dan melakukan penelitian langsung di lapangan, berupa memberikan pertanyaan langsung kepada para responden. Variabel yang diamati dalam penelitian ini adalah sebagai berikut: a). Komponen modal dalam usa pembibitan sapi bali; b). Penggunaan tenaga kerja; c). Faktor penguasaan lahan, dan d). Manajemen pemeliharaan dalam usaha pembibitan sapi bali. Hasil penelitian menunjukkan bahwa secara umum faktorfaktor jumlah penguasaan lahan dan manajemen pemeliharaan terutama pengelolaan aspek reproduksi (calving interval) yang mencapai 18 bulan berdampak pada rendahnya tingkat produktivitas ternak sapi bali.

\section{Pendahuluan}

Sapi Bali merupakan salah satu komoditi unggulan dan penggerak roda perekonomian di Kabupaten Timor Tengah Utara. Selama ini kendala utama petani dalam meningkatkan populasi ternak sapi bali adalah keterbatasan jumlah sapi bibit. Salah satu penyebabnya adalah banyak sapi betina produktif yang dipotong, dan pengelolaan sistem usaha ternak yang masih belum dikelola dengan baik.

Sistem usaha ternak sapi bali adalah suatu sistem usaha yang terdiri dari komponen-komponen yang saling berkaitan terhadap usaha pemeliharaan sap bali. Peternak memilih mengusahakan ternak sapi dengan beberapa tujuan. Bag peternak, ternak sapi bali berfungsi sebagai sumber pendapatan, sumber protein hewani, dan tenaga kerja serta penghasil pupuk. Fungsi lain adalah sebagai penghasil bibit dan bersifat tabungan.

Sejauh ini, masih banyak aspek tentang sistem pemeliharaan ternak sap bali secara ekstensif belum dapat dipahami secara utuh dan mendalam. Akibatnya belum dapat dirancang suatu model pengembangan yang holisttic dan handal untuk diterapkan di tingkat petani maupun secara komersial. Pemahaman terhadap sistem yang sedemikian kompleks masih bersifat parsial, padahal proses produksi dalam sistem pemeliharaan ekstensif melibatkan interaksi antara iklim, tanah, tanaman, ternak, tatalaksana, dan sosio-ekonomi masyarakat. Dengan demikian, maka sangat jelas bahwa sistem pemeliharaan ternak secara ekstensi bersifat spesifik lokasi.

Kondisi peternakan sapi bali di daerah ini sebenarnya cukup memprihatinkan. Penelitian Jelantik $d k k$., (2007) mencatat bahwa sebagian besa ternak sapi bali yang diekspor maupun dipotong untuk konsumsi lokal, bukan dihasilkan dari sistem peternakan yang produktif dan efisien, melainkan dar sistem peternakan tradisional dengan tingkat produktivitasnya rendah.

Saat ini sebenarnya banyak permasalahan yang timbul dalam dunia peternakan. Salah satunya adalah semakin sempitnya padang penggembalaan yang mengakibatkan menurunnya jumlah produksi pakan, sehingga berakiba pada penurunan pendapatan petani itu sendiri. Seiring dengan hal tersebut di atas, banyak petani yang berinisiatif melakukan pekerjaan sampingan atau penganekaragaman pertanian guna mengatasi menurunnya tingkat ketersediaan pakan salah satunya dengan membentuk atau mendirikan kelompok ternak sapi.

Upaya untuk meningkatkan pengembangan sapi bali perlu didukung sistem pembibitan yang ideal di tingkat petani. Demikian juga kemampuan ternak sapi untuk dapat beradaptasi dengan lingkungan termasuk kondisi pakan yang tersedia sesuai dengan pola pertanian yang dilakukan petani.

Desa Kuaken merupakan salah satu desa yang berada ada Kecamatan Noemuti Kabupaten Noemuti Timur, yang memiliki masyarakat sebagian besarnya adalah petani peternak yang mempunyai ide dan berhasil mendirikan sebuah kelompok tani, yang diberi nama "Kelompok Tani Cipta Kasih." Kelompok Tani ini bergerak pada usaha pembibitan dan penggemukan ternak sapi bali jantan.

Anggota kelompok tani Cipta Kasih sadar betul akan pentingnya ternak sapi, yang merupakan salah satu sumber daya penghasilan bahan makanan, berupa; daging yang memiliki nilai ekonomis tinggi dan penting artinya di dalam kehidupan manusia. Selain menghasilkan bahan makanan berupa daging, ternak sapi juga menghasilkan hasil ikutan lainnya seperti pupuk kandang, kompos, kulitnya, dan lain sebagainya.

Pola pembibitan yang di lakukan oleh Kelompok Tani Cipta Kasih tidak terlepas dari faktor-faktor produksi yang mempengaruhi hasil usaha pembibitan sapi bali tersebut. Faktor produksi adalah sumber daya yang dipergunakan dalam sebuah proses produksi barang dan jasa. Faktor-faktor produksi yang dimaksud seperti tenaga kerja, modal, tanah dan manajemen.

\section{Metode}

Penelitian ini telah dilaksanakan pada Kelompok Tani Cipta Kasih Desa Kuaken, Kecamatan Noemuti Timur, Kabupaten Timor Tengah Utara. Penelitian berlangsung selama 1 (satu) bulan yakni pada bulan Mei 2018 sampai dengan selesai. Penentuan responden secara purposive sampling dengan pertimbangan memiliki lebih dari satu sapi bali yang masuk dalam program pembibitan dan dengan pengalaman beternak lebih dari 4 tahun. Ternak yang akan digunakan dalam penelitian ini adalah induk Sapi Bali sebanyak 76 ekor induk yang dimiliki oleh kelompok Tani Cipta Kasih desa Kuaken Kecamatan Noemuti Timur Metode yang dipakai dalam penelitian adalah metode survey dan melakukan penelitian langsung di lapangan, berupa memberikan pertanyaan langsung kepada para responden.

Data yang diperoleh dalam penelitian ini di analisa dengan menggunakan analisa deskriptif yaitu menghitung nilai rata-rata dari masing-masing variabel, standar deviasi dan koefisien keragaman dengan formulasi sesuai Sugiyono (2005).

\section{Hasil dan Pembahasan}

\subsection{Gambaran Umum Desa Kuaken}

Desa Kuaken merupakan salah satu Desa yang berada di wilayah Kecamatan Noemuti Timur, Kabupaten Timor Tengah Utara Provinsi Nusa Tenggara Timur, dengan luas wilayah (daratan) adalah $7500 \mathrm{ha} / \mathrm{m}^{2}$ atau $18,48 \%$ dari luas wilayah Kecamatan Noemuti Timur. Ada pun batas-batas wilayah Desa Kuaken yaitu: Barat berbatasan dengan Desa Nibaaf, Kecamatan Noemuti, bagian Timur berbatasan dengan Desa Manikin Kecamatan Noemuti Timur, bagian Utara berbatasan dengan Desa Naiola Kecamatan Bikomi Selatan dan bagian Selatan berbatasan dengan Desa Naop Kecamatan Noemuti Timur.

Secara umum Desa Kuaken juga sama dengan daerah lain memiliki dua musim yakni musim kemarau, yang terjadi pada bulan Juni sampai September, sedangkan musim hujan pada bulan Desember sampai Maret. Namun setahun terakhir telah terjadi perubahan periode musim yang cukup signifikan, yakn waktu hujan menjadi lebih panjang dibanding tahun-tahun sebelumnya (BPS Kab. TTU, 2016). Sedangkan Kelompok Tani Cipta Kasih merupakan salah satu kelompok tani yang berada di wilayah Desa Kuaken, yang keberadaannya disahkan melalui Surat Keputusan (SK) Kepala Desa Kuaken Nomor: 12/SK/V/2007 tentang pengukuhan Kelompok Tani Cipta Kasih, sebagai kelompok tani kelas Pemula Desa Kuaken, Kecamatan Noemuti Timur.

\subsection{Karakteristik Responden}

Karakteristik responden yang diperoleh meliputi tingkat pendidikan, umur, pengalaman beternak dan pekerjaan utama. Keempat aspek tersebut dapa mempengaruhi keikutsertaan para responden dalam mengelola kegiatan usaha pembibitan ternak sapi bali. Karakteristik tersebut dapat menjadi salah satu yang menyebabkan para responden mengadopsi kegiatan agar tercapai tujuan yang diinginkan yakni meningkatkan kesadaran dalam mengembangkan pembibitan komoditas ternak sapi bali. Oleh karena itu pembahasan tentang faktor-faktor produksi yang mempengaruhi usaha pembibitan sapi bali diawali dari komponen karakteristik responden yang dapat diuraikan sebagai berikut:

a. Tingkat Pendidikan Responden

Tingkat pendidikan peternak merupakan latar belakang keadaan peternak yang dapat mempengaruhi tingkat pengelolaan usaha pembibitan ternak sapi bali. Tingkat pendidikan dapat pula menjadi salah satu faktor dalam menentukan keberhasilan usaha pembibitan sapi bali di kalangan peternak. Rata-rata persentase tingkat pendidikan yang dimiliki peternak seperti disajikan pada Tabel 1

Tabel 1. Tingkat Pendidikan Peternak

\begin{tabular}{cccc}
\hline No. & Tk. Pendidikan & Jumlah & Persentase $(\%)$ \\
\hline 1 & SD & 10 & 66.67 \\
2 & SMP & 3 & 20.00 \\
3 & SMA & 2 & 13.33 \\
\hline & $\sum$ & 15 & 100.00
\end{tabular}


Data pada Tabel 1. menunjukkan bahwa rata-rata peternak SD sebanyak 10 orang dari 15 responden yang ada dengan nilai persentase $66,67 \%$, pendidikan SMP sebanyak 3 orang dari 15 responden dengan nilai persentase $20,00 \%$, pendidikan SMA sebanyak 2 orang dari 15 responden dengan nilai persentase $13,33 \%$. Hal ini mengindikasikan bahwa umumnya tingkat pendidikan yang dimiliki oleh peternak rendah yakni hanya berpendidikan SD, sehingga cukup sulit dalam menerima inovasi baru dan berdampak pada usaha yang dijalankan cukup membutuhkan waktu yang relatif lama untuk berkembang.

Tingkat pendidikan yang rendah menyebabkan seseorang kurang mempunyai keterampilan tertentu yang diperlukan dalam kehidupannya. Keterbatasan keterampilan/pendidikan yang dimiliki menyebabkan keterbatasan kemampuan untuk masuk dalam dunia kerja (Ahmadi, 2003).

b. Umur Responden.

Umur merupakan salah satu faktor yang mempengaruhi perilaku dan kinerja dalam suatu usaha, di mana produktivitas kerja akan meningkat bila masih dalam kondisi umur yang masih produktif dan semakin menurun seiring bertambahnya umur seseorang. Peternak yang memiliki usia yang lebih muda cenderung lebih cekatan dalam menjalankan usahanya, dibanding peternak yang usianya cenderung lebih tua. Walau demikian peternak yang lebih tua memiliki pengalaman serta strategi yang banyak dalam beternak dibandingkan dengan peternak yang usianya masih muda. Kondisi ini tentunya menjadi kelebihan dan kekurangan yang ada pada peternak dalam menjalankan usaha pembibitan ternak sapi bali. Rata-rata umur yang dimiliki para peternak disajikan pada Tabel 2.

Tabel 2. Umur Responden/Peternak

\begin{tabular}{cccc}
\hline No. & Umur & Jumlah & Persentase (\%) \\
\hline 1 & $33-43$ & 5 & 33.33 \\
2 & $44-52$ & 3 & 20.00 \\
3 & $53-60$ & 4 & 26.67 \\
4 & $61-70$ & 2 & 13.33 \\
5 & $>71$ & 1 & 6.67 \\
\hline & $\sum$ & 15 & 100.00 \\
\hline
\end{tabular}

Umur peternak merupakan salah satu faktor yang bisa mempengaruhi kemampuan peternak dalam mengelola usaha pembibitan ternak sapi bali. Hal ini dapat mempengaruhi kemampuan kerja dalam mengambil tindakan serta berpengaruh dalam pola pikir masing-masing peternak. Data Tabel 2. menjelaskan bahwa sebagian besar peternak sapi bali di kelompok Tani Cipta Kasih Desa Kuaken berada pada usia yang relatif produktif. Hasil penelitian menunjukkan rata-rata umur peternak sapi bali di Kelompok Tani Cipta Kasih Desa Kuaken adalah 33 sampai 43 tahun (produktif) yakni 5 orang dengan nilai persentase $33,33 \%$. Umur 44 sampai 52 tahun (produktif) sebanyak 3 orang dengan nilai persentase $20,00 \%$. Keadaan umur peternak 53 sampai 60 tahun (produktif) yakni sebanyak 4 orang dengan nilai persentase $26,67 \%$, dan sisanya umur antara 61 sampai 71 tahun (non produktif) yakni sebanyak 3 orang dengan nilai persentase $20 \%$ tersebut memberikan gambaran bahwa peternak di lokasi penelitian secara umum berada dalam kategori umur produktif. Hal ini sesuai dengan pernyataan Suratiyah (2005), bahwa kisaran usia 15 sampai 60 tahun termasuk usia produktif sedangkan usia lebih dari 60 tahun dikategorikan usia non produktif. Usia peternak menentukan kapasitas pengelolaan terhadap usaha peternakan khususnya peternakan sapi bali. Peternak yang berusia muda mempunyai fisik yang kuat sehingga dapat bekerja secara maksimal dan efektif. Peternak yang telah lanjut usia kondisi fisiknya cenderung sudah menurun, namun disisi lain senantiasa diharapkan pada pekerjaan fisik yang berat.

c. Pengalaman Beternak

Deskripsi responden menurut pengalaman usaha menguraikan seberapa lama responden menggeluti usaha pembibitan ternak sapi bali yang menjadi sampel dalam penelitian ini. Pengalaman usaha yang telah dipatri dalam diri seseorang akan turut mempengaruhi sikap dan perilakunya dalam bertindak. Oleh karna itulah perlu dideskripsi karakteristik responden menurut pengalaman usaha sebagaimana data dalam Tabel 3. berikut.

Tabel 3. menunjukkan bahwa dominan pengalaman beternak dari para peternak usaha pembibitan ternak sapi bali di kelompok tani Cipta Kasih Desa Kuaken Kecamatan Noemuti Timur adalah 10 sampai14 tahun berjumlah 6 orang dengan nilai persentase 40,00\%. Menyusul pengalaman usaha 5 sampai 9 tahun dengan jumlah 4 orang dengan nilai persentase $26,67 \%$.

Andrinof (2006), menjelaskan bahwa semakin lama pengalaman beternak, maka peternak akan semakin efisien atau tingkat efisiensi semakin tinggi dan cenderung semakin mudah peternak dalam mengambil keputusan dalam berhubungan dengan teknis pemeliharaan usaha pemeliharaan ternaknya.

Tabel 3. Pengalaman Beternak Responden

\begin{tabular}{cccc}
\hline No. & Pengalaman beternak & Jumlah & Persentase (\%) \\
\hline 1 & $5-9$ & 4 & 26.67 \\
2 & $10-14$ & 6 & 40.00 \\
3 & $15-19$ & 2 & 13.33 \\
4 & $20-24$ & 2 & 13.33 \\
5 & $>25$ & 1 & 6.67 \\
\hline \multicolumn{4}{c}{} \\
\hline
\end{tabular}

\section{d. Pekerjaan Utama Responden}

Deskripsi karakteristik responden menurut jenis pekerjaan menguraikan atau memberikan gambaran mengenai identitas responden menurut jenis pekerjaan responden. Dalam deskripsi karakteristik responden dikelompokkan menurut jenis pekerjaan responden yang dapat dilihat melalui Tabel 4. sebagai berikut.

Tabel 4. Pekerjaan Responden

\begin{tabular}{cccc}
\hline No. & Pekerjaan & Jumlah & Persentase (\%) \\
\hline 1 & Petani & 12 & 93.33 \\
2 & Peternak & 1 & 6.67 \\
\hline & $\sum$ & 15 & 100.00 \\
\hline
\end{tabular}

Berdasarkan Tabel 4. tersebut di atas, diketahui bahwa sebagian besar jenis pekerjaan responden adalah petani yaitu sebanyak 14 orang atau 93,33\%. Hal ini dikarenakan sebagian besar penduduk di seluruh desa Kuaken, kecamatan Noemuti Timur bermata pencaharian sebagai petani dan terdapat1 orang responden atau 6,67\% menggeluti pekerjaan sebagai peternak.

Pada data di atas juga menunjukkan bahwa pekerjaan utama responden adalah petani, dan usaha peternakan sapi Bali hanya dilakukan sebagai pekerjaan sampingan dan hanya 1 orang saja peternak sapi Bali yang menjadikan peternak sebagai pekerjaan utama mereka. Hal ini disebabkan oleh kurangnya kesadaran dari peternak akan profit yang bisa diperoleh dalam usaha peternakan sapi Bali, sehingga dapat diasumsikan bahwa peternakan sapi Bali masih berpeluang untuk dikembangkan apa bila beternak dijadikan sebagai pekerjaan utama.

\subsection{Komponen Modal dalam Usaha Pembibitan Sapi Bali}

Komponen modal yang diamati dalam penelitian ini meliputi jenis modal (bergerak dan tidak bergerak) dan cara memperoleh modal yang penjabarannya seperti terlihat pada Tabel 5 .

Tabel 5. Jenis dan Asal Modal

\begin{tabular}{|c|c|c|c|c|c|}
\hline No. & Uraian/Variabel Pengamatan & Jumlah & $\%$ & SD & KK \\
\hline \multirow[t]{3}{*}{1} & Jenis Modal & & & & \\
\hline & a. Lahan + ternak & 12 & 80,00 & 0.362 & 0,757 \\
\hline & b. Lahan + bangunan kandang + ternak & 3 & 20,00 & 0.439 & 0,963 \\
\hline \multirow[t]{4}{*}{2} & Cara memperoleh Modal & & & & \\
\hline & a. Warisan & 8 & 53,33 & 0.610 & 1.221 \\
\hline & b. Beli & 4 & 26,67 & 0.472 & 1.651 \\
\hline & c. Beli + warisan/hibah & 3 & 20,00 & 0.415 & 1.938 \\
\hline
\end{tabular}

Data pada Tabel 5. di atas menunjukkan bahwa terdapat $80 \%$ (12 orang) peternak mengatakan memiliki modal merupakan lahan dan ternak terdapat $20 \%$ ( 3 orang) peternak yang mengatakan jenis faktor modal yang dimiliki berupa lahan, ternak dan bangunan kandang ternak. Untuk cara peternak memperoleh modal terlihat bahwa terdapat $53.33 \%$ (8 orang) mendapatkan modal dari warisan, 26,67\% (4 orang) memperoleh modal dengan cara membeli sendiri dan $20 \%$ sisanya (3 orang) memperoleh modal dari kombinasi membeli dan mendapat warisan.

Dari analisis hasil yang dipaparkan mengindikasikan bahwa komponen modal yang digunakan dalam usaha pembibitan ternak sapi bali di Kelompok Tani Cipta Kasih Desa Kuaken tidak banyak sebab peternak mengandalkan semua dari alam dalam pemberian pakan dengan cara menggembalakan di padang rumput dan pemeliharaan juga dilakukan di luar kandang atau digembalakan di padang rumput. Pada pemeliharaan semi-intensif, kandang yang dibangun dengan menggunakan bahan yang sangat sederhana, misalnya fondasi kandang dibuat dari batu atau semen, tiang dari kayu atau bambu, atap dari gewang/daun lontar, dengan rangka atap dari bahan bambu atau kayu, lantai kandang dari tanah yang dipadatkan, tetapi ada pula yang menggunakan semen. Kandang pada umumnya tidak memakai sekat dinding dengan tujuan agar sirkulasi udara di dalam kandang tetap terjaga dan sinar matahari tetap dapat masuk ke dalam kandang.

Sistem pemeliharaan tersebut kurang baik karena ternak tidak terlindungi dari hujan dan terik matahari, tidak terkontrolnya pemberian pakan, pengaturan perkembangbiakan, pengawasan terhadap kesehatan dan pencegahan penyakit. Oleh karena sistem pemeliharaan yang ekstensif, tidak jarang dari peternak yang tertukar sapinya dengan peternak lain dan peternak sudah terbiasa dengan hal ini. Risiko pencurian ternak sapi potong di Desa Mangkai Lama terbilang jarang terjadi karena hampir semua peternak banyak yang membiarkan begitu saja ternaknya untuk digembalakan. Cara lain yang dilakukan peternak dalam menghindari pencurian ternak adalah dengan memberikan tanda yakni berupa kaleng kalung pada leher ternak sapi.

\subsection{Penggunaan Tenaga Kerja dalam Usaha Pembibitan Sapi Bali}

Usaha peternakan pada dasarnya merupakan kegiatan utama bagi peternak di perdesaan, di mana hasil produksinya sepenuhnya di arahkan ke pasar, dan jarang sekali ditemui bahwa peternak langsung mengonsumsi sendiri hasil ternak dalam pemeliharaan atau hasil dibudidaya sendiri. Hasil analisis data tentang penggunaan tenaga kerja dalam usaha pembibitan sapi bali di kelompok tani Cipta Kasih dapat dilihat pada Tabel 6.

Data pada Tabel 6. di atas menunjukkan bahwa untuk faktor produksi tenaga kerja mayoritas menggunakan tenaga kerja keluarga yaitu sebanyak 
$86,67 \%$ (13 orang) peternak dan hanya $13,33 \%$ (2 orang) peternak yang menggunakan tenaga kerja dari luar, sedangkan dari aspek pengalokasian waktu yang dibutuhkan dalam sehari untuk mengurus ternak (curahan waktu kerja) menunjukkan bahwa terdapat $66,67 \%$ (10 orang) peternak yang mengatakan bahwa waktu yang dibutuhkan untuk mengurus ternaknya rata-rata 3 jam; terdapat $20 \%$ (3 orang) peternakan yang menggunakan waktu kerja 4 jam dalam sehari dan hanya 13,33\% (2 orang) peternak yang menghabiskan waktu lebih dari 4 jam sehari untuk mengurusi ternak-ternak sapi bali peliharaannya.

Tabel 6. Penggunaan Tenaga Kerja

\begin{tabular}{clcccc}
\hline No. & Uraian/Variabel Pengamatan & Jumlah & $\%$ & SD & KK \\
\hline 1 & Penggunaan Tenaga Kerja & & & & \\
\hline & a. Luar & 2 & 13.33 & 0.350 & 2.450 \\
& b. Keluarga & 13 & 86.67 & 0.789 & 0.920 \\
\hline 2 & Curahan Waktu Kerja & & & & \\
\hline & a. 3 jam & 10 & 66.67 & 0.687 & 1.069 \\
& b. 4 jam & 3 & 20.00 & 0.415 & 1.938 \\
& c. $>$ 4 jam & 2 & 13.33 & 0.350 & 2.450 \\
\hline
\end{tabular}

Peternak sapi bali di kelompok tani Cipta Kasih Desa Kuaken memanfaatkan tenaga kerja yang berasal dari dalam keluarga untuk aktivitas usaha pembibitan ternaknya dan hanya 2 orang peternak yang menggunakan tenaga kerja dari luar keluarga, dengan demikian peternak memiliki proporsi yang besar dalam memelihara ternaknya. Peternak setiap harinya melakukan tugas seperti menggiring ternak sapi ke wilayah penggembalaan selanjutnya ternak sapi akan memakan rumput dengan sendirinya, daerah tersebut juga terdapat aliran sungai kecil sehingga apabila ternak ingin minum akan pergi dengan sendirinya ke sumber air tersebut. Beberapa peternak menggiring kembali ternaknya pada sore hari untuk dibawa pulang dan dimasukkan ke dalam kandang, beberapa peternak lainnya membiarkan ternaknya digembalakan diwilayah penggembalaan.

Menurut Novra (2015), bahwa usaha pemeliharaan ternak sapi dengan sistem penggembalaan akan berimplikasi pada tingkat produktivitas ternak yang rendah. Hasil penelitian Rusdiana $d k k$., (2010) bahwa berbeda dengan usaha tan tanaman, tatalaksana usaha ternak pola intensif umumnya mempunyai kegiatankegiatan rutin yang bersifat mencari pakan, memberi makan/ransum membersihkan kandang, memandikan sehingga menyerap tenaga keluarga yang cukup besar.

\subsection{Penguasaan Lahan}

Lahan sebagai salah satu faktor produksi yang penting dalam usaha/ budidaya ternak. Adapun besaran penguasaan lahan peternak pada usaha pembibitan ternak sapi bali di kelompok tani Cipta Kasih Desa Kuaken dapat dilihat pada Tabel 7 .

Tabel 7. Faktor Produksi Lahan

\begin{tabular}{cccccc}
\hline No. & Uraian/Variabel Pengamatan & Jumlah & $\%$ & SD & KK \\
\hline 1 & Status Lahan & & & & \\
\hline a. Bersertifikat & 13 & 86.67 & 0.789 & 0.920 \\
& b. Non Sertifikat & 2 & 13.33 & 0.350 & 2.450 \\
\hline 2 & Luas Lahan & & & & \\
\hline a. $0.5-1$ & 10 & 66.67 & 0.687 & 1.069 \\
& b. $>1-2$ & 4 & 26.67 & 0.472 & 1.651 \\
& c. $>2$ & 1 & 6.67 & 0.269 & 3.770 \\
\hline
\end{tabular}

Lahan merupakan faktor produksi yang mewakili unsur alam dan lahan merupakan faktor yang relatif langka dibanding dengan faktor produksi lain serta distribusi penguasaannya tidak merata di masyarakat. Data pada Tabel 7. di atas menunjukkan bahwa terdapat $86,67 \%$ (13 orang) peternak yang memiliki lahan dengan status bersertifikat dan hanya terdapat $13,33 \%$ ( 2 orang) peternak dengan status kepemilikan lahan yang belum bersertifikat. Untuk luas kepemilikan lahan peternak tergambar bahwa petani memiliki luas lahan yang relatif kecil di mana terdapat $66,67.33 \%$ (10 orang) dengan rata-rata luas lahan antara 0,5 sampai 1 hektar; $26,67 \%$ (4 orang) peternak dengan luasan lahan lebih dari 1 sampai 2 hektar dan hanya $6,67 \%$ (1 orang) peternak yang memiliki luas lahan lebih dari 2 hektar.

Rendahnya luasan kepemilikan lahan yang dimiliki peternak berdampak pada ketersediaan pakan, di mana dengan luasan lahan yang tidak lebih dari 1 hektar peternak hanya dapat menghasilkan hijauan pakan ternak yang terbatas, sehingga kekurangan pakan ternak disiasati dengan pola pemeliharaan ternak yang ekstersif (digembalakan di padang). Menurut Mubyarto (1989) tanah/lahan sebagai salah satu faktor produksi yang merupakan pabrik hasil-hasil pertanian yaitu tempat di mana produksi berjalan dan dari mana hasil produksi keluar.

\subsection{Manajemen Pemeliharaan}

Manajemen pemeliharaan dan perawatan ternak merupakan salah satu kunci penting dalam usaha ternak sapi bali. Sebab pemeliharaan yang baik akan menentukan berhasil/tidaknya suatu usaha. Adapun beberapa variabel yang digunakan dalam mengkaji pengelolaan pemeliharaan ternak sapi bali dalam usaha pembibitan ternak di kelompok tani Cipta Kasih Desa Kuaken dapat dilihat pada Tabel 8 .
Data pada Tabel 8. menunjukkan bahwa terdapat $73,33 \%$ (11 orang) peternak mengelola usaha pembibitan ternak sapi bali dengan sistem pemeliharaan ekstensif dan hanya terdapat $26,67 \%$ (4 orang) peternak yang memelihara ternak sapi balinya dengan sistim pemeliharaan semi intensif. Semi intensif dimaksud adalah pemeliharaan dengan pola digembalakan di padang pada siang hari dan pada malam hari ternak-ternak digiring kembali ke kandang untuk selanjutnya diberi pakan tambahan.

Data pada Tabel 8. juga menunjukkan bahwa dari aspek pengelolaan reproduksi yang diterapkan peternak pada usaha pembibitan sapi bali di kelompok tani Cipta Kasih sistem perkawinan ternaknya dilakukan secara alami (kawin alam) dan belum adanya teknologi Inseminasi Buatan (IB), sedangkan pada aspek jarak beranak (calving interval) terlihat bahwa dari populasi induk betina terdapat $52,63 \%$ (40 ekor) dengan jarak beranak 18 bulan, menyusul $36,84 \%$ atau sebanyak 28 ekor ternak betina dengan jarak beranak 12 bulan dan sisanya $10,53 \%$ ( 8 ekor) ternak dengan jarak beranaknya 15 bulan.

\begin{tabular}{|c|c|c|c|c|c|}
\hline No. & Uraian/Variabel Pengamatan & Jumlah & $\%$ & SD & KK \\
\hline \multirow[t]{3}{*}{1} & Sistim pemeliharaan & & & & \\
\hline & a. Ekstensif (Penggembalaan) & 11 & 73.33 & 0.757 & 0.963 \\
\hline & b. Semi intensif & 4 & 26.67 & 0.415 & 1.938 \\
\hline \multirow[t]{4}{*}{2} & Pakan & & & & \\
\hline & a. Rumput & 2 & 13.33 & 0.350 & 2.450 \\
\hline & b. Rumput + legum & 9 & 60.00 & 0.687 & 1.069 \\
\hline & c. Pakan tambahan (Putak) & 4 & 26.67 & 0.415 & 1.938 \\
\hline \multirow[t]{5}{*}{3} & Reproduksi & & & & \\
\hline & $\begin{array}{l}\text { a. Sistem perkawinan } \\
\text { - Alam } \\
\text { b. Jarak beranak }\end{array}$ & 76 & 100 & 0.850 & 0.850 \\
\hline & -12 bulan & 28 & 36.84 & 0.568 & 1.325 \\
\hline & -15 bulan & 8 & 10.53 & 0.723 & 6.865 \\
\hline & - 18 bulan & 40 & 52.63 & 0.650 & 1.235 \\
\hline
\end{tabular}

Sistem pemeliharaan ekstensif yang dimaksud adalah cara pemeliharaan sapi bali yang digembalakan pada siang hari dan dikandangkan pada malam hari, maupun yang dilepas bebas di padang atau hutan dan hanya dikumpulkan oleh pemiliknya pada saat-saat tertentu saja. Dalam kondisi ini, proses kehidupan ternak hampir sepenuhnya terjadi secara alami di padang penggembalaan, dan intervensi peternak sangat minim.

Sistem pemeliharaan tersebut kurang baik karena ternak tidak terlindungi dari hujan dan terik matahari, tidak terkontrolnya pemberian pakan, pengaturan perkembangbiakan, pengawasan terhadap kesehatan dan pencegahan penyakit Oleh karena sistem pemeliharaan yang ekstensif, tidak jarang dari peternak yang tertukar sapinya dengan peternak lain dan peternak sudah terbiasa dengan hal ini. Risiko pencurian ternak sapi potong di desa Kuaken terbilang jarang terjadi karena hampir semua peternak banyak yang membiarkan begitu saja ternaknya untuk digembalakan. Cara lain yang dilakukan peternak dalam menghindari pencurian ternak adalah dengan memberikan tanda yakni berupa pemberian cap bakar dan atau pemberian kaleng kalung pada leher ternak sapi.

Bila melihat dapat aspek reproduksi di atas mengindikasikan bahwa belum optimalnya daya reproduksi ternak secara baik, hal ini dapat dicirikan dari calving interval yang relatif panjang (15 - 18 bulan) dalam pemeliharaan di tingkat peternak. Panjangnya calving interval ini pada akhirnya akan mengakibatkan produktivitas secara keseluruhan menjadi turun. Panjang calving interval yang diinginkan adalah 12 bulan. Siklus melahirkan setahun satu kali, hanya dapat dicapai jika sapi-sapi induk memiliki tingkat konseption rate yang tinggi dan sapi bali memang memilikinya, deteksi birahi yang akurat (untuk sapisapi yang dipelihara individual atau hanya induk saja) sehingga interval waktu yang pendek yaitu hanya sekitar 90 hari sejak kelahiran sampai bunting kembali atau days open dapat dimanfaatkan secara sempurna (Pelssier, 1996). Hal in disebabkan karena periode calving interval tergantung pada lama bunting, involusi uterus, reoestrus postpartum, jumlah siklus yang dibutuhkan untuk memperoleh kebuntingan (Mukasa, 2009).

Untuk mencapai peningkatan populasi maka yang perlu dilakukan adalah pengaturan perkawinan dengan menggunakan pejantan terseleksi, kecukupan pakan untuk induk, pengaturan perkawinan untuk memperoleh calving rate tertinggi, usaha untuk meningkatkan survival rate dari pedet dan meningkatkan jumlah pedet yang dapat mencapai usia yearling. Sedangkan untuk meningkatkan produktivitas per individu maka langkah yang harus ditempuh adalah menyeleksi pejantan, calon pejantan pengganti, induk yang baik dan secara perlahan mengeluarkan sapi-sapi jantan maupun betina yang kurang produktif menjadi ternak konsumsi. Selain perbaikan pada pengaturan pakan perlu adanya pengaturan/pengawasan perkawinan ternak di lapangan untuk menghasilkan derajat inbreeding rendah.

\section{Simpulan}

Berdasarkan uraian hasil dan pembahasan di atas maka dapat ditarik kesimpulan bahwa secara umum faktor-faktor jumlah penguasaan lahan khususnya pada pakan dan manajemen pemeliharaan terutama pengelolaan aspek reproduksi (calving interval) yang mencapai 18 bulan berdampak pada rendahnya tingkat produktivitas ternak sapi bali. 
Pustaka

Ahmadi A. H. 2003. Sosiologi Pendidikan. Penerbit PT. Rineka Cipta, Jakarta.

Andrinof D. 2006. Analisis Pola Kemitraan Peternakan Ayam Pedaging pada Peternak Plasma PT. Satwa Mirama Raya Di Kabupaten Malang.

BPS. 2016. Kabupaten Timor Tengah Utara

Jelantik IGN, Manggol YH, Jegho Y, Sutedjo H, Keban A, Kune P, Ratu D, Kleden R, Sogen MM, Kleden J. 2007. Kajian Mutu Genetik Sapi Bali di Nusa Tenggara Timur. [laporan akhir]. Kupang (ID): Universitas Nusa Cendana.

Mubyarto. 2001. Pengantar Ekonomi Pertanian. LP3ES. Jakarta.

Mukasa Mugerwa . 2009. A review of reproductive performance of female bosindicus (zebu) cattle. Dalam: Monografi. No. 6. International Livestock center for Africa.

Novra A. 2015. Subsidi Bunga Modal yang Diterima Rumah Tangga Peternak Sapi Betina Program SCR (Corporate Social Responsibility) Petrochina Jabung Ltd. Agriekonomia 4(2): 122-131.

Pelisier.1996. Pelissier, C.L. 1996. Identification of Reproductive Problems and Their Economic Consequences. dalam: Proceedings of National Invitational Dairy Cattle Reproduction Workshop. Louisville, KY.

Sugiyono. 2005. Metodologi Penelitian Kualitatif, Bandung: Alfabeta.

Suratiyah K. 2005. Ilmu Usaha Tani. Penebar Swadaya, Yogyakarta.

Rusdiana S., B Wibowo, L Praharani, 2010. Penyerapan Sumberdaya Manusia Dalam Analisis Fungsi Usaha Sapi Potong Rakyat di Pedesaan. Prosiding Seminar Nasional Peternakan dan Veteriner Puslitbangnak Bogor Oktober 2010. Hal. 453-460. 